\title{
Optimal Law Enforcement and Criminal Organization *
}

\author{
Nuno GAROUPA ${ }^{\dagger}$ \\ Universitat Pompeu Fabra \\ Email: garoupa@upf.es
}

March 1999

\begin{abstract}
In this paper, we take an organizational view of organized crime. In particular, we study the organizational consequences of product illegality attending at the following characteristics: (i) contracts are not enforceable in court, (ii) all participants are subject to the risk of being punished, (iii) employees present a major threat to the entrepreneur having the most detailed knowledge concerning participation, (iv) separation between ownership and management is difficult because record-keeping and auditing augments criminal evidence.
\end{abstract}

${ }^{*}$ Discussions with Andrew Daughety, John Donohue, Antony Dnes, Erling Eide, Hugh Gravelle, Mike Klausner, Dan Klerman, Kai Konrad, Adriana Kugler, Peter Jost, Brian Main, David Mills, Mitch Polinsky, Jennifer Reinganum, Tom Saving, Steven Shavell, and Stergios Skaperdas were very important. Financial support from FCT, Lisbon, Portugal is gratefully acknowledged. The usual disclaimer applies.

${ }^{\dagger}$ Department d'Economia i Empresa, Universitat Pompeu Fabra, Ramon Trias Fargas 25-27, 08005 Barcelona, Spain, Phone:+34-93-5422639, Fax:+34-93-5421746. 


\section{Introduction}

The economic analysis of crime has its starting point with Becker's (1968) seminal work: individuals rationally decide whether to engage in criminal activities by comparing the expected returns to crime with the returns to legitimate business. Hence, crime is less attractive if the government increases the probability (certainty) and severity of punishment. Alternatively, by increasing market opportunities, one makes crime less attractive. Becker's main thesis is that since imposing a fine is costless, this fine should equal an individual's entire wealth and be complemented by a probability of punishment to optimally deter crime.

Economic literature on organized crime is quite scarce as compared to the work by economists on crime and criminal law. ${ }^{1}$ The first papers essentially stressed welfare comparisons of different market structures. Buchanan (1973) and Backhaus (1979) discuss the thesis that a monopolistic market is more efficient than a perfect competitive one in presence of harmful offenses because the output is smaller. More recently, Dick $(1995,1998)$ has developed an analytical framework in which transaction costs, rather than monopoly power, primarily determine the activities of organized criminal firms. The paper predicts that organized crime is more successful when there is production cost advantage. ${ }^{2}$

Most of the literature on organized crime has focused on the market structure. In this paper, we propose an organizational view of organized crime. Previous work by Reuter (1983), Abadinsky (1987) and Turvani

\footnotetext{
${ }^{1}$ See Garoupa (1997) and Polinsky and Shavell (1999).

${ }^{2} \mathrm{~A}$ similar argument is summarized by Posner (1998), pages 264-66.
} 
(1997) has pointed out the importance of transaction costs on criminal organizations. In particular, Turvani (1997) argues that because activities are illegal, the usual institutional environment of a developed market economy cannot provide a positive framework for monitoring transactions. As a result, limited vertical integration arises and most contractual relationships resemble a de facto hostage.

In this paper, we study the organizational consequences of product illegality. In particular, we attend at the following characteristics: (i) contracts are not enforceable in court, (ii) all participants are subject to the risk of being punished, (iii) employees present a major threat to the entrepreneur having the most detailed knowledge concerning participation, (iv) separation between ownership and management is difficult because record-keeping and auditing augments criminal evidence.

Illegal contracts are not enforceable in court. That is not to say that illegal contracts are not enforceable. As noted by Reuter (1983), Gambetta (1994), Robinson (1994), and Skaperdas (1998), most of these contracts are self-enforcing. The literature on self-enforcing contracts poses that some kind of vertical integration assures self-enforcement. ${ }^{3}$ On the other hand, Reuter (1983) argues that in criminal markets violence is a substitute for vertical integration. Hence, one mechanism to enforce an illegal contract is the threat and use of violence.

The participants in illegal markets lack access to state-provided facilities for settlement of disputes. Consequently, violence is an effective method to resolve disputes. Furthermore, victims of violence are disadvantaged in

\footnotetext{
${ }^{3}$ See Klein and Murphy (1997).
} 
seeking police protection: the process of providing an informative complaint will convey information to the police about the illegal activities of the complainant.

Recent economic analysis of the role of violence in criminal organizations includes Jennings (1984), Grossman (1995), Polo (1995), Skaperdas and Syropoulos (1995), Konrad and Skaperdas (1997, 1998), and Garoupa (1999). The general view is that reputation is quite appealing to support an equilibrium with self-enforcing contracts where violence is relatively rare. Such theoretical conclusion seems to have empirical support as cited by Reuter (1983). Violence arises when the criminal organization wants to monopolize the market or avoid competitive entry. Moreover, in the long run, the violent gang is usually replaced by reputation increasing profits and saving on labor costs. The threat of violence also affects the organization of the market $e x-$ ante by avoiding misunderstandings and controlling the degree of subjective uncertainty.

A second mechanism to enforce an illegal contract is recurring to Mafia's arbitration. Reuter (1983) mentions the Mafia as a social dispute solving institution, and Kelly (1987) refers to the social and political system created by organized criminal institutions. Seeking Mafia's arbitration can be of advantage to criminal firms because violence is costly and uncertain: the cost of acquiring reputation is high in an environment where disputes are frequent. Moreover, there is a complete absence of feasible symbols of quality and reliability. On the supply side, allowing the Mafia to act as a referee, solves the problem of defining property rights. ${ }^{4}$

\footnotetext{
${ }^{4}$ Reuter (1983) summarizes the characteristics of the Mafia's judicial system: (I) only Mafia members can act as dispute settlers; (II) there is no market for representatives;
} 
In terms of the present paper, the important observation is that enforcing contracts in the criminal world is costly, either because violence is not inexpensive (even if only at a threat level) or because solving the matter within the Mafia's institutional system is not costless (it may include costs of arbitration, rents to be paid as subscription, bribes). Our model is of a criminal franchising. Within the franchising literature, as in Mathewson and Winter (1985), we assert that the contracting firm favors an ex-ante fixed fee than an ex-post share of the profits because of contractual enforcement costs.

Given that enforcing criminal contracts is expensive, one poses that a criminal organization should prefer an employment relationship rather than subcontracting. Monitoring and enforcing a contract is relatively easier in an employment relationship as pointed out by Klein and Murphy (1997). The cost of monitoring subcontractors is augmented because there is not book-auditing and record-keeping must be minimal to reduce evidence.

The problem posed by an employee is that his detection can compromise the whole organization with higher probability than an external subcontractor. Employees can provide information about past and future deals leading to arrest and seizure of assets involved in the transaction. The entrepreneur aims then to structure the relationship so as to reduce the amount of information available to them concerning his own participation and to ensure that they have minimal incentive to inform against him. Moreover, employees are afraid of other employees. Thus dispersion and monitoring naturally emerges as to control individual risk.

(III) no set of substantive rules to govern settlements; (IV) participants regard decision as self-enforcing; (V) hierarchy of illegal firms is respected. 
As pointed out by Reuter (1983), illegal firms should be smaller than if the product were legal. In this paper, we investigate the optimal response to the trade-off between monitoring costs and apprehension. In policy terms, the most immediate remark is that, for a given expenditure on detection, sanctioning more severely the subcontractor than the subcontracted offenders affects not only the dimension but also the characteristics of a criminal network. As a consequence, we argue that severe punishment reduces the dimension of the network but it might augment the effectiveness of its members. Eventually smaller firms are easier to manage and consequently less mistakes are committed diminishing the likelihood of detection.

The paper goes as follows: we develop a formal contractual model of organized crime and derive the optimal public policy in section two. In section three, we study the possibility of plea bargaining. In section four, we analyze asymmetries of information between franchisor and franchisees. Final remarks are addressed in section five.

\section{A Formal Franchising Model of Organized Crime}

Consider a criminal firm that decides to engage in criminal activities. We model this criminal firm as a franchisor deciding at time 1 on the number $n$ of franchisees and the terms of the franchising contracts. At time 2, a monitoring game is played between the franchisor, the franchisees, and the law enforcement agency. Those detected are consequently punished for their criminal acts. We must solve this game backwards for subgame perfection. 
The expected payoff of a risk neutral franchisee is:

$$
V=b+x(i)-p(c, i) f-y
$$

where $b$ is the gain from committing an offense that varies across the population according to a uniform distribution with support $[0,1] ; x(i)$ is the productivity gain enhanced by criminal know-how expenditure $i$ borne by the franchisor, where $x_{i}>0$ and $x_{i i}<0 ; p$ is the probability of a franchisee being detected and punished by the government, $c$ is the government's expenditure on law enforcement, $i$ is criminal know-how expenditure borne by the franchisor, including the cost of information about the organization, $f$ is a monetary sanction measuring the severity of punishment, and $y$ is the royalty to be paid to the franchisor. We further assume that $p_{c}>0, p_{c c}<0$, $p_{i}<0, p_{i i}>0$, and $p_{i c}<0 .^{5}$

A franchising contract is a pair $\langle y, i\rangle$ that maximizes the franchisor's expected profits subject to an incentive constraint. Let us normalize the franchisee's opportunity cost to zero. A franchisee accepts the contract if and only if:

$$
V=b+x(i)-p(c, i) f-y \geq 0
$$

The royalties equal $b+x(i)-p(c, i) f$. As in Mathewson and Winter (1985), we know that the franchisor is able to extract the whole surplus through a fixed payment. In the context of illegal business, extracting the surplus through an initial fixed payment is more attractive since there is no third party contractual enforcement for participation contracts.

\footnotetext{
${ }^{5}$ We can think of $p($.$) as a contest success function (CSF). See Skaperdas (1996) for$ discussion. Criminal know-how could also be interpreted as a protection activity. See Alexander (1997) for an economic analysis.
} 
Defining $\beta$ as the lower bound on $b$ such that the franchisor is willing to hire (and given the assumption of a uniform distribution, $n=1-\beta$ ), the expected profits of the franchisor are:

$$
\Pi=\int_{\beta}^{1}[b+x(i)-p(c, i) f-q(c, i) s-i] d b
$$

where $s$ is the monetary sanction per-franchisee paid by the franchisor if detected and punished, $s n$ is the monetary sanction paid by the franchisor if detected and punished, $q(c, i)$ is the probability of detection and punishment of a franchisor where $q_{c}>0, q_{c c}<0, q_{i}>0, q_{i i}>0$, and $q_{i c}<0$.

The franchisor's expected punishment is $q(c, i) s n$. An alternative interpretation is to say that the technology of detection has constant returns to scale in the number of franchisees, and $s$ is the monetary sanction.

The first-order conditions with respect to $\beta$ and $i$ are the following:

$$
\begin{gathered}
\Pi_{\beta}=p(i, c) f+q(i, c) s+i-x(i)-\beta=0 \\
\Pi_{i}=\int_{\beta}^{1}\left[x_{i}-p_{i} f-q_{i} s-1\right] d b=0
\end{gathered}
$$

Given that the second-order conditions are satisfied ${ }^{6}$, one derives $\beta^{*}(c, f, s)$

${ }^{6}$ The second-order conditions are:

$$
\begin{gathered}
\Pi_{\beta \beta}=-1<0 \\
\Pi_{i i}=\int_{\beta}^{1}\left[x_{i i}-p_{i i} f-q_{i i} s\right] d b<0 \\
\Pi_{\beta i}=0
\end{gathered}
$$

So that the Hessean has a positive determinant:

$$
H=\Pi_{\beta \beta} \Pi_{i i}
$$


and $i^{*}(c, f, s)$. The number of franchisees is decreasing in these three parameters whereas the criminal know-how is increasing in the government's expenditure $c$ and the franchisee's sanction $f$ but decreasing in the franchisor's sanction $s$.

Corollary 1 A legal franchisor hires more franchisees.

The fact that an illegal activity is subject to punishment distorts the optimal dimension of the firm. Such observation is a trivial consequence of the deterrence effect of penalties. The marginal value of hiring a franchisee is reduced with the probability and severity of punishment. More interestingly, note that not only a criminal firm is of a smaller dimension but also the criminal partnership is sensitive to the structure of penalties:

Corollary 2 In general, the information structure of a legal franchising differs from an illegal one. The direction of that difference (more or less knowhow is provided) depends on the relative magnitudes of the punishment faced by the franchisor versus that of the franchisee.

The sanctioning structure $\langle f, s\rangle$ affects the internal structure of the firm. Note that $x_{i}-1=p_{i} f+q_{i} s$. A system where the franchisor is much more penalized than the franchisee leads to less criminal know-how being provided, that is, a franchising where less information about the organization is shared. However, a system where the franchisor is much less penalized than the franchisee leads to more criminal know-how being provided, that is, a franchising where more information about the organization is shared. In a sense, a system that strongly penalizes the franchisees induces a much stronger partnership in terms of increasing $i^{*}$. 
Corollary 3 The dimension of the illegal franchising is a concave function on criminal know-how expenditure achieving its maximum when such expenditure is optimally set.

From (4), we have:

$$
\Pi_{\beta i}=p_{i} f+q_{i} s+1-x_{i}
$$

And we know that $i=i^{*}$ is a minimum from (5). An illegal franchising where information is not provided is of a smaller dimension than an illegal where information is optimally provided. The intuition is that franchisees are more likely to be detected in this case and there are no productivity gains. Conversely, an illegal franchising where too much information is provided is of a smaller dimension because the franchisor is more likely to be detected.

\section{Optimal Policy}

The government announces at time 0 the law enforcement policy. The social cost of the illegal activity is given by $h\left(1-\beta^{*}\right)+c$, where $h$ is the harm caused by each offense (independent of criminal productivity) and $c$ the cost of law enforcement. The government's objective is to solve:

$$
\left[p\left(c, i^{*}\right) f+q\left(c, i^{*}\right) s\right]\left(1-\beta^{*}\right)=h\left(1-\beta^{*}\right)+c
$$

for $f, s$, and $p$. For a given $f$ and $s$, we can solve (6) for a given $c$, say $\hat{c}$. Note that, as in Shavell (1997), the allocation of sanctions between franchisor and franchisees is irrelevant from the government's viewpoint as long as we can solve (6) (even though it affects the internal structure of the firm). A possible solution is $s=0$ and $f>0$ as in Garoupa (1999). 
Nonetheless, if the expenditure $\hat{c}$ is sufficiently high, we have $\Pi(\hat{c})<0$ and so the criminal franchising is driven out of the market. If the criminal franchising does not operate, the economy bears a social cost given by $\hat{c}$. In other words, deterring completely the criminal franchising is eventually too costly.

An alternative approach is to argue that a government should maximize social welfare where criminal gains are included ${ }^{7}$ :

$$
W=\int_{\beta^{*}}^{1}\left[b+x\left(i^{*}\right)-i^{*}-h\right] d b-c
$$

subject to the usual constraints $f \leq F$ and $s \leq S$ where $F$ and $S$ can be interpreted as franchisee's and franchisor's entire (exogenous) wealth respectively. The first-order conditions with respect to $c, f$, and $s$ are $^{8}$ :

$$
\begin{gathered}
W_{c}=-1+[h-p f-q s] \beta_{c}^{*}+\int_{\beta^{*}}^{1}\left[x_{i}-1\right] i_{c}^{*} d b=0 \\
W_{f}=[h-p f-q s] \beta_{f}^{*}+\int_{\beta^{*}}^{1}\left[x_{i}-1\right] i_{f}^{*} d b \geq 0 \\
W_{s}=[h-p f-q s] \beta_{s}^{*}+\int_{\beta^{*}}^{1}\left[x_{i}-1\right] i_{s}^{*} d b \geq 0
\end{gathered}
$$

Proposition 1 (1) One optimal monetary sanction must be maximal, (2) If $x_{i}>1$, the sanction borne by the franchisee must be maximal, (3) If $x_{i}<1$, the sanction borne by the franchisor must be maximal, (4) If $x_{i}=1$, both sanctions must be maximal.

\footnotetext{
${ }^{7}$ See Garoupa (1997) and Polinsky and Shavell (1999) for discussion about including criminal gains in social welfare.

${ }^{8}$ The second-order conditions are assumed to be satisfied. A sufficient condition is to impose sufficiently large decreasing returns to scale so that $p_{c c}<<0$ and $q_{c c}<<0$.
} 


\section{Proof of Proposition 1}

Solve for interior solutions: $W_{f}=0$ and $W_{s}=0$. We can show that in this case for $x_{i} \neq 1$ :

$$
p / q=i_{f}^{*} / i_{s}^{*}
$$

Noting that the left-hand-side is strictly positive and the right-hand-side is strictly negative, we can say that this cannot be the solution of the optimization problem. Therefore, both sanctions cannot be less than maximal. We proceed to write:

$$
W_{s}-W_{f} \beta_{s}^{*} / \beta_{f}^{*}=\int_{\beta^{*}}^{1}\left(x_{i}-1\right)\left[i_{s}^{*}-i_{f}^{*} \beta_{s}^{*} / \beta_{f}^{*}\right] d b
$$

The sign of the right-hand-side depends on the social value of information $x_{i}-1$. Case (1): $x_{i}<1$. The right-hand-side of the expression is positive. As a consequence, it can be the case that $W_{f}=0$ and $W_{s}>0$ but cannot be $W_{f} \geq 0$ and $W_{s}=0$. Case (2): $x_{i}>1$. The right-hand-side of the expression is negative. As a consequence, we cannot have $W_{f}=0$ and $W_{s} \geq 0$ but we can have $W_{s}=0$ and $W_{f}>0$. Case (3): $x_{i}=1$. The right-hand-side of the expression is zero. This is the usual Becker (1968) result. Both sanctions must be maximal. For a detailed proof see Garoupa (1997).

The choice of sanctions is directly related to its effect on criminal knowhow expenditure. Define $i^{\prime}$ as the optimal expenditure on criminal-know when the business is legal. Hence it must be $x_{i}\left(i^{\prime}\right)=1$. Note that $x_{i}\left(i^{*}\right)>$ $x_{i}\left(i^{\prime}\right)$ is equivalent to $i^{*}<i^{\prime}$.

Corollary 4 If when legal, the franchisor provides more information about the organization, the sanction borne by the franchisee must be maximal and the sanction borne by the franchisor can be less than maximal. 
Information about the business is welfare improving because it augments the net surplus of this activity. The sanction borne by the franchisor affects negatively the provision of criminal-know how. Consequently, setting it at its highest value could damage the net surplus too much.

Corollary 5 If when legal, the franchisor provides less information about the organization, the sanction borne by the franchisor must be maximal and the sanction borne by the franchisee can be less than maximal.

On the contrary, in this second corollary, information about the business is welfare diminishing because it reduces the net surplus of this activity. The sanction borne by the franchisee affects positively the provision of criminalknow how. Consequently, setting it at its highest value could damage the net surplus too much.

Note that the argument for a less severe punishment differs from Malik (1991). In Malik's paper, individuals who commit a crime can engage in a costly avoidance activity. Because such avoidance activity is socially costly and increases with the severity of punishment, a less severe punishment can be optimal. Here the problem relates to the fact that the avoidance activity could be socially beneficial (given that it increases productivity) and different sanctions have opposite effects.

\section{A Model with Plea Bargaining}

An important assumption for some of the results derived in the previous section is that $q_{i}>0$, that is, the probability of detection and conviction of 
the franchisor increases with expenditure in criminal know-how. The argument behind such assumption has been discussed previously and refers to the fact that a more informed franchisee can compromise the whole organization. By introducing the possibility of plea bargaining, we aim at modeling this argument and analyze the positive relationship between the probability of detection and conviction of the franchisor and criminal know-how. ${ }^{9}$

When detected, a franchisee faces a monetary sanction $f$. In return for evidence against the franchisor, the government might be willing to reduce such monetary sanction. Let us assume that the government's policy is to randomize the decision of entering into plea bargaining with probability $r$. We can think that the decision depends on a random variable that is revealed at the end of the game, say a random opportunity or reputation cost. Alternatively, given the risk neutrality assumption, the government offers the possibility of a discount $r$ on the criminal sanction in return for evidence.

The government is willing to offer such agreement if the franchisor has not been detected and convicted. Otherwise, there is no need for the evidence that the franchisee might provide. For sake of argument, we pose that the probability of detection and conviction of a franchisor without evidence provided by a franchisee is zero. However, if a franchisee provides evidence, the franchisor faces a probability $\gamma(i)$ of being convicted where $\gamma_{i}>0$ and $\gamma_{i i}<0$.

The expected payoff of a risk neutral franchisee is now:

$$
V=b+x(i)-p(c, i)(1-r) f-y
$$

\footnotetext{
${ }^{9}$ See Adelstein and Miceli (1997) for a review on the economic literature of pleabargaining.
} 
Note that for $r \leq 1$ the expected payoff of a franchisee increases when the possibility of a plea bargaining is considered.

Defining $\beta$ as the lower bound on $b$ such that the franchisor is willing to hire, the expected profits of the franchisor are:

$$
\Pi=\int_{\beta}^{1}[b+x(i)-p(c, i)(1-r) f-p(c, i) r \gamma(i) s-i] d b
$$

A first remark is that using previous notion we can see $q(c, i)=p(c, i) \gamma(i)$. We have specified the probability of punishment of the franchisor as a function of that of the franchisee. It is also clear where the positive relation between the likelihood of a franchisor being punished and criminal knowhow comes from. The probability $q($.$) is monotonically increasing in i$ if $\gamma_{i} / \gamma>-p_{i} / p$ for all $i$. The interpretation is the following: the higher likelihood of being detected and convicted if the franchisor provides more information always offsets the lower likelihood of a franchisee being detected and convicted.

A second observation is that the possibility of plea bargaining does not reduce the franchising expected surplus:

$$
\Pi_{r}=\int_{\beta}^{1}[p(c, i) f-q(c, i) s] d b
$$

Franchisees have a less severe expected punishment because of the possibility of plea bargaining and that allows the franchisor to charge more royalties increasing expected profits. On the other hand, the possibility of plea bargaining increases the likelihood of detection and conviction of the franchisor reducing expected profits. The net effect depends on the magnitude of expected sanctions for the franchisor and franchisee. 
The first-order conditions with respect to $\beta$ and $i$ are the following:

$$
\begin{gathered}
\Pi_{\beta}=p(i, c)(1-r) f+q(i, c) r s+i-x(i)-\beta=0 \\
\Pi_{i}=\int_{\beta}^{1}\left[x_{i}-p_{i}(1-r) f-q_{i} r s-1\right] d b=0
\end{gathered}
$$

Given that the second-order conditions are satisfied as before, one derives $\beta^{*}(c, f, s, r)$ and $i^{*}(c, f, s, r)$.

Corollary 6 When the expected sanction faced by the franchisee is less severe than that of the franchisor, the relation between the dimension of the franchising and the likelihood of plea bargaining is negative.

When the likelihood of plea bargaining $r$ increases, the expected payoff of a franchisee increases and hence the number of franchisees should increase. However, the likelihood of an agreement between prosecution and franchisee is higher. The expected punishment of the franchisor increases making hiring more franchisees less attractive:

$$
\Pi_{\beta r}=q(i, c) s-p(i, c) f
$$

Generally, we cannot say that the possibility of plea bargaining with franchisees affects negatively the dimension of the criminal firm (because of the royalties).

Corollary 7 The relation between the provision of information by the franchisor and the likelihood of plea bargaining is negative.

The relation between criminal know-how and the likelihood $r$ is determined by:

$$
\Pi_{i r}=\left(p_{i} f-q_{i} s\right)(1-\beta)<0
$$


A policy of plea bargaining in return for evidence against the franchisor weakens the internal structure of the firm.

\section{Optimal Policy}

Posing that a government should maximize social welfare including criminal gains, we have:

$$
W=\int_{\beta^{*}}^{1}\left[b+x\left(i^{*}\right)-i^{*}-h\right] d b-c
$$

subject to the usual constraints $f \leq F$ and $s \leq S$. In this setting we have assumed that the likelihood of plea bargaining $r$ is costless to apply. The first-order conditions with respect to $c, f$, and $s$ are not formally different from (8)-(10). The first-order condition with respect to $r$ is:

$$
W_{r}=[h-p f-q s] \beta_{r}^{*}+\int_{\beta^{*}}^{1}\left[x_{i}-1\right] i_{r}^{*} d b \geq 0
$$

The optimal likelihood of plea bargaining (or the optimal discount) depends on (a) its impact on the dimension of the firm and (b) the marginal social value of criminal know-how.

Corollary 8 When the likelihood of plea bargaining affects positively the dimension of the franchising and $x_{i}>1$, its optimal value is zero.

Corollary 9 When the likelihood of plea bargaining affects negatively the dimension of the franchising and $x_{i}<1$, its optimal value is one.

When $\beta_{r}^{*}$ is positive (increasing the likelihood of plea bargaining reduces the dimension of the firm), the role of $r$ is analytically similar to $s$, that is, 
depending on the marginal social value of criminal know-how, the government should set $r^{*}$ equal to one or to an interior solution. However, when $\beta_{r}^{*}$ is negative (increasing the likelihood of plea bargaining augments the dimension of the firm), criminal immunity could be problematic.

\section{A Model with Asymmetric Information}

The plausibility of the franchisor knowing exactly the value of $b$ for each potential franchisee is quite low. In the context of legal markets, individuals' productivity is private information and is at heart of adverse selection problems. The possibility that individual productivity is verifiable by the franchisor in an illegal market is even more remote since feasible symbols of quality and reliability are rare. Most of the time, the illegal franchisor hires franchisees without a reasonable information set about their productivity. Furthermore, because productivity verification is difficult and essentially there is no third-party contractual enforcement, franchisees have a clear incentive to signal a low productivity reducing ex-ante royalties. The low productivity is of course constrained by $\beta$, that is, the lowest level of productivity that the franchisor is willing to accept. In short, each franchisee such that $b \geq \beta$ reports individual productivity to be $\beta$ and consequently pays $y(\beta)=\beta+i-p(c, i) f$ generating a rent given by $b-\beta$. The franchisor is not able to extract the whole surplus as in a context of perfect information.

As we are going to show, asymmetry of information does not simply generate different sharing rules of criminal gains within the franchising. The franchisor anticipates that franchisees will imitate the lowest productive individual reducing profits. Therefore, the franchisor has an incentive to increase 
$\beta$ reducing the dimension of the franchising in return for an increase in royalties. The expected profits of the franchisor are:

$$
\hat{\Pi}=\int_{\beta}^{1}[\beta+x(i)-p(c, i) f-q(c, i) s-i] d b
$$

The first-order condition with respect to $i$ is (5), and with respect to $\beta$ yields:

$$
\hat{\beta}=1 / 2+[p(i, c) f+q(i, c) s+i-x(i)] / 2
$$

Since we get the optimal criminal know-how to be $i^{*}$, we can write:

$$
\hat{\beta}=1 / 2+\beta^{*} / 2
$$

Consequently,

Corollary 10 The dimension of the criminal franchising is reduced when there is asymmetry of information about productivity.

Moreover, we can show:

$$
\hat{\Pi}=\Pi+\int_{\hat{\beta}}^{1}(\hat{\beta}-b) d b-\int_{\beta^{*}}^{\hat{\beta}}\left[b+x\left(i^{*}\right)-p\left(c, i^{*}\right)-q\left(c, i^{*}\right)-i^{*}\right] d b
$$

The second term refers to the loss in revenues from asymmetric information; the third term refers to the loss from reducing the dimension of the franchising, and hiring fewer franchisees. We can see immediately that the optimal choice of $\hat{\beta}$ is driven by the trade-off of these two effects. 


\section{Optimal Policy}

Posing that a government should maximize social welfare including criminal gains, we have:

$$
\begin{aligned}
\hat{W} & =\int_{\hat{\beta}}^{1}\left[b+x\left(i^{*}\right)-i^{*}-h\right] d b-c \\
& =W-\int_{\beta^{*}}^{\hat{\beta}}\left[b+x\left(i^{*}\right)-i^{*}-h\right] d b
\end{aligned}
$$

Asymmetry of information about productivity is welfare improving because not only it reduces the dimension of the franchising but also increases the average productivity of franchisees. Note that these two properties are also present in a legal franchising but in such case they are welfare diminishing. Grossly, and ignoring gains in know-how, the critical level of productivity for a legal franchising is zero and for an illegal franchising is $h$ from a social viewpoint. With symmetric information, we have seen that $0 \leq \beta^{*} \leq h$. And, with asymmetric information, the critical level of productivity satisfies $\hat{\beta} \geq \beta^{*}$. Therefore:

Corollary 11 Asymmetry of information about productivity is socially ben-

eficial if the franchising is illegal and is socially detrimental if the franchising is legal.

From this corollary, it is clear that activities aiming at reducing asymmetry of information about productivity should be deterred. In essence, $\hat{W}-W$ is the maximum price that a government should be willing to pay to deter such activities. 
The first-order conditions with respect to $c, f$, and $s$ are analytically similar to (8)-(10). Hence the results obtained in Proposition 1 are valid within a context of asymmetry of information. Furthermore,

Proposition 2 Assume that both sanctions are maximal and $x_{i} \geq 1$. The optimal expenditure on law enforcement is greater in a context of symmetric information than in a context of asymmetric information.

\section{Proof of Proposition 2}

For a given $F$ and $S$, we can write:

$$
\hat{W}_{c}=W_{c}-[h-p f-q s] \beta_{c}^{*} / 2-\left(\hat{\beta}-\beta^{*}\right) \beta_{c}^{*} / 2-\int_{\beta^{*}}^{\hat{\beta}}\left[x_{i}-1\right] i_{c}^{*} d b=0
$$

It is straightforward that:

$$
\hat{W}_{c}\left(c^{*}\right)=-[h-p f-q s] \beta_{c}^{*} / 2-\left(\hat{\beta}-\beta^{*}\right) \beta_{c}^{*} / 2-\int_{\beta^{*}}^{\hat{\beta}}\left[x_{i}-1\right] i_{c}^{*} d b<0
$$

where $c^{*}$ is the optimal expenditure on law enforcement in a context of symmetric information.

The intuition is that asymmetric information reduces the dimension of the franchising allowing the government to save on law enforcement. The importance of the second assumption comes from the fact by reducing the franchising, the marginal gain in productivity is also reduced. By reducing expenditure on law enforcement the marginal loss in productivity is less important. Such observation is valid as long as $x_{i} \geq 1$, that is, as long as the marginal gain is positive. For $x_{i}<1$, when the marginal gain is negative, there is an argument to increase expenditure on law enforcement. 
Asymmetry of information within the franchising is welcomed by the government because it reduces the dimension of the franchising and saves on enforcement. Consequently, activities aiming at reducing asymmetry of information should be deterred. This observation further justifies why violence is socially detrimental. The treat and use of violence plays a role in conveying information about the type of franchisee to the franchisor. ${ }^{10}$ Abstracting from its direct social cost, violence is costly because reduces informational problems within the franchising.

\section{$5 \quad$ Final Remarks}

Economic analysis of organized crime is relatively scarce compared to the growing literature on crime and criminal law. ${ }^{11}$ In Garoupa (1999) we extend the optimal law enforcement literature to organized crime by discussing different market structures. In this paper, we approach the question from a contractual perspective.

In this paper, we have argued that severe punishment certainly reduces the dimension of a criminal network but it might augment the effectiveness of its members. Eventually smaller firms are easier to manage and consequently less mistakes are committed diminishing the likelihood of detection. Hence a less severe enforcement of the law should be considered.

The second important conclusion is that the possibility of plea bargaining with subcontracted offenders that provide evidence against the subcon-

\footnotetext{
${ }^{10}$ And vice-versa; see Garoupa (1999).

${ }^{11}$ See Garoupa(1997) and Polinsky and Shavell (1999) for references.
} 
tractor is not necessarily welfare improving. The rationale is that ex-ante it makes the criminal contract more attractive for both parts. For the subcontracted because the expected punishment is less severe. For the subcontractor because it augments royalties.

The third important conclusion is that asymmetry of information between franchisor and franchisees is welfare improving for two reasons: it reduces the dimension of the franchising, and consequently permits a reduction on law enforcement expenditure. Activities that reduce the asymmetry of information should be deterred. This observation further justifies why violence is socially detrimental. The treat and use of violence plays a role in conveying information about the type of franchisee to the franchisor. Abstracting from its direct social cost, violence is costly because reduces informational problems within the franchising.

\section{References}

1. Abadinsky, H., 1987, The McDonald's-ization of the Mafia, in Organized Crime in America: Concepts and Controversies, edited by $\mathrm{T}$. Bynum. Criminal Justice Press: New York.

2. Adelstein, R. and Miceli, T.J., 1997, Toward a comparative economics of plea bargaining, University of Connecticut mimeo.

3. Alexander, B., 1997, The rational racketeer: pasta protection in Depression Era Chicago, Journal of Law and Economics, vol. 40, pages 175-202. 
4. Backhaus, J., 1979, Defending organized crime? A note, Journal of Legal Studies, vol. 8, pages 623-631.

5. Becker, G., 1968, Crime and punishment: an economic analysis, Journal of Political Economy, vol. 76, pages 169-217.

6. Buchanan, J. M., 1973, A defense of organized crime?, in The Economics of Crime and Punishment, edited by S. Rottenberg. American Enterprise Institute.

7. Dick, A. R., 1995, When does organized crime pay? A transaction cost analysis, International Review of Law and Economics, vol. 15, pages $25-45$.

8. Dick, A. R., 1998, Organized crime, in The New Palgrave Dictionary of Economics and the Law, edited by P. Newman, Macmillan: London.

9. Gambetta, D., 1994, Inscrutable Markets, Rationality and Society, vol. 6 , pages 334-352.

10. Garoupa, N., 1997, The theory of optimal law enforcement, Journal of Economic Surveys, vol. 11, pages 267-295.

11. Garoupa, N., 1999, The economics of organized crime and optimal law enforcement, Economic Inquiry, Forthcoming.

12. Grossman, H. I., 1995, Rival kleptocrats: the mafia versus the state, in The Economics of Organised Crime, edited by G. Fiorentini and S. Peltzman, Cambridge University Press and CEPR.

13. Jennings, W. P., 1984, A note on the economics of organized crime, Eastern Economic Journal, vol. 3, pages 315-321. 
14. Kelly, R. J., 1987, The nature of organized crime and its operations, in Major Issues in Organized Crime Control, edited by H. Edelhertz, National Institute of Justice.

15. Klein, B., and Murphy, K., 1997, Vertical integration as a self-enforcing contractual arrangement, American Economic Review, vol. 87, pp. 415-420.

16. Konrad, K. A. and Skaperdas, S., 1997, Credible threats in extortion, Journal of Economic Behavior and Organization, vol. 33, pages 23-39.

17. Konrad, K. A. and Skaperdas, S., 1998, Extortion, Economica, 65, 461-477.

18. Malik, A. S., 1990, Avoidance, Screening and Optimum Enforcement, RAND Journal of Economics, vol. 21, pages 341-353.

19. Mathewson, G. F., and Winter, R. A., 1985, The economics of franchise contracts, Journal of Law and Economics, vol. 28, pages 503-526.

20. Polinsky, A. M. and Shavell, S., 1999, The economic theory of public enforcement of law, NBER Working-Paper 6993.

21. Polo, M., 1995, Internal cohesion and competition among criminal organisations, in The Economics of Organised Crime, edited by G. Fiorentini and S. Peltzman, Cambridge University Press and CEPR.

22. Posner, R., 1998, Economic analysis of law, Aspen Law \& Business: New York.

23. Reuter, P., 1983, Disorganized crime, MIT Press: Cambridge, Massachusetts. 
24. Robinson, J., 1994, The laundrymen: inside the world's third largest business, Pocket Books: London.

25. Skaperdas, S., 1996, Contest success functions, Economic Theory, vol. 7, pages $283-290$.

26. Skaperdas, S., 1998, Gangs and the state of nature, in The New Palgrave Dictionary of Economics and the Law, edited by P. Newman, Macmillan: London.

27. Skaperdas, S., and Syropoulos, C., 1995, Gangs as primitive states, in The Economics of Organised Crime, edited by G. Fiorentini and S. Peltzman, Cambridge University Press and CEPR.

28. Turvani, M., 1997, Illegal markets and the new institutional economics, in Transaction Cost Economics, edited by C. Menard, Edward Elgar: Cheltenham. 